\title{
Biomethanation potential of macroalgae Ulva spp. and Gracilaria spp. and in co-digestion with waste activated sludge
}

\author{
J.C. Costa *, P.R. Gonçalves, A. Nobre ${ }^{1}$, M.M. Alves \\ IBB - Institute for Biotechnology and Bioengineering, Centre of Biological Engineering, Universidade do Minho, 4710-057 Braga, Portugal
}

\section{A R T I C L E I N F O}

\section{Article history:}

Received 13 January 2012

Received in revised form 2 March 2012

Accepted 2 March 2012

Available online 10 March 2012

\section{Keywords:}

Anaerobic digestion

Biochemical methane potential

Macroalgae

UIva sp

Waste activated sludge

\begin{abstract}
A B S T R A C T
Biochemical methane potential of four species of Ulva and Gracilaria genus was assessed in batch assays at mesophilic temperature. The results indicate a higher specific methane production (per volatile solids) for one of the Ulva sp. compared with other macroalgae and for tests running with $2.5 \%$ of total solids (196 $\pm 9 \mathrm{~L} \mathrm{CH}_{4} \mathrm{~kg}^{-1} \mathrm{VS}$ ). Considering that macroalgae can potentially be a post treatment of municipal wastewater for nutrients removal, co-digestion of macroalgae with waste activated sludge (WAS) was assessed. The co-digestion of macroalgae (15\%) with WAS (85\%) is feasible at a rate of methane production $26 \%$ higher than WAS alone without decreasing the overall biodegradability of the substrate $(42-45 \%$ methane yield). The use of anoxic marine sediment as inoculum had no positive effect on the methane production in batch assays. The limiting step of the overall anaerobic digestion process was the hydrolysis.
\end{abstract}

(C) 2012 Elsevier Ltd. All rights reserved.

\section{Introduction}

In the seventies, the oil crisis resulted in a strong interest in the macroalgae cultivation for energy production, which was abandoned because the economic climate returned to favor fossil fuels (Briand and Morand, 1997; Chynoweth et al., 2001). Due to the recent oil crisis (with consequent increase in oil prices in international markets) and the creation of policies to mitigate greenhouse gases, after the Kyoto Protocol, the exploitation of renewable energy sources has regain considerable interest. For instance, in the European Union (EU), according with Directive 2009/ 28/EC, the Council of March 2007 set a binding target of $20 \%$ share of energy from renewable sources in overall EU energy consumption by 2020 .

Anaerobic digestion (AD) is a process responsible for the degradation of most of the carbonaceous matter in natural environments where organic accumulation results in oxygen depletion (Appels et al., 2008). In particular, AD of energy crops and organic wastes benefits society by promoting a cleaner fuel (biogas) than fossil fuels and a bio-fertilizer (digested matter) from renewable raw materials (Appels et al., 2011).

$\mathrm{AD}$ of biowaste and energy crops has a role in the EU policy of energy and environment. Several research programs have investigated energy crops (aquatic and terrestrial) for methane produc-

\footnotetext{
* Corresponding author. Tel.: +351 253604 400; fax: +351253604 429.

E-mail address: carloscosta@deb.uminho.pt (J.C. Costa).

${ }^{1}$ Current address: SIMTEJO - Saneamento Integrado dos Municípios do Tejo e Trancão, SA, Avenida Defensor de Chaves, $45,2^{\circ}$. 1000-112 Lisboa, Portugal.
}

tion (Appels et al., 2011; Chynoweth et al., 2001). These programs integrated several data, including, data from crop production, harvesting, conversion to methane, and system analysis. Estimates indicate that the energy potential of marine biomass is more than $100 \mathrm{EJ} \mathrm{yr}^{-1}$, significantly higher than the terrestrial biomass $\left(22 \mathrm{EJ} \mathrm{yr}^{-1}\right.$ ) or municipal solid waste $\left(7 \mathrm{EJ} \mathrm{yr}^{-1}\right.$ ) (Chynoweth et al., 2001). Furthermore, algal biomass presents high productivity rates, do not compete for land with crops, has tolerance to a wide range of temperature, salinity and nutrient concentrations, and, there is an extensive knowledge about their farming practices (Bruhn et al., 2011; Gunasselan, 1987; Hansson, 1983; Jones and Mayfield, 2011; Nielsen and Heiske, 2011; Schamm and Lehnberg, 1984). Macroalgae contain easily hydrolysable sugars and proteins; low fractions of lignin (Gunasselan, 1987; Nkemka and Murto, 2010) and high fractions of hemicellulose, which favor the enzymes accessibility to the substrate; and a good hydrolysis yield (Briand and Morand, 1997). Other advantages of aquatic biomass, such as macroalgae, over terrestrial biomass, include area availability and high growth rates (Bruhn et al., 2011; Gunasselan, 1987; Hansson, 1983).

Macroalgae have the potential of becoming a viable aquatic energy crop (Bruhn et al., 2011; Chynoweth et al., 2001; Gao and Mickinley, 1994; Hansson, 1983; Morand et al., 1990, 2006). However, the production of energy from macroalgae is still committed for reasons of economic viability (Jones and Mayfield, 2011). One possibility is the cultivation of macroalgae using nutrients from wastewater treatment plants (WWTP) and subsequent production of biogas from the cultivated biomass alone or in co-digestion with waste activated sludge (WAS) in existing digesters. Other benefits 
of co-digestion includes: dilution of the potential toxicity of any of the involved co-substrates, nutrients balance, synergistic effects on microorganisms, increasing the load of biodegradable organic matter, and higher methane yields per unit of digester volume (Cecchi et al., 1996; Nkemka and Murto, 2010). Yen and Brune (2007) reported a significant enhancement of the methane production with an addition of paper waste to algal sludge. However, using Ulva sp. as a co-substrate with pig manure ( $48 \%: 52 \% \mathrm{w} / \mathrm{w})$, no significant improvements were observed (Peu et al., 2011). Another possibility to increase the biodegradability extent and rate of macroalgae is to use an inoculum more adapted to the substrate, such as anoxic marine sediments. In fact, Schamm and Lehnberg (1984) obtained higher methane yield using marine sediment because of the specific affinity of the methanogenic archaea to the macroalgae.

Biochemical methane potential (BMP) tests are commonly used to estimate the extent of anaerobic biodegradability of substrates and the associated specific methane production (Angelidaki et al., 2009). Also, BMP assays results can provide a rough estimate of residence times required for complete digestion of a given substrate (Labatut et al., 2010).

The aim of this work was to determine the BMP of several raw macroalgae and macroalgae co-digested with WAS. The effect of using anoxic marine sediment, instead of anaerobic suspended sludge, as inoculum was also assessed. The tested macroalgae included common species that grow wild and also cultivated.

\section{Methods}

\subsection{Substrates}

The following species of macroalgae were used: Ulva spp. (U), including a species previously classified as Enteromorpha genus and hereafter identified as (UE), Gracilaria sp. (G), and Gracilaria vermicullophyla $(\mathrm{GV})$.

The macroalgae Ulva spp., and Gracilaria sp. were collected in the Sapalsado aquaculture input tanks (Sado Estuary, Faralhão, Portugal), where they grow naturally. The macroalgae G. vermiculophylla was harvested from an experimental integrated multi-trophic aquaculture implemented in a fish monoculture in the North of Portugal (Abreu et al., 2010). To facilitate the milling process, the macroalgae were dried at $105^{\circ} \mathrm{C}$ for $24 \mathrm{~h}$ in an oven, and then milled into pieces with less than $0.5 \mathrm{~cm}$.

Activated aerobic sludges from different stages of treatment in the WWTP of Beirolas (Lisbon, Portugal) were used as co-substrate: primary sludge (PS), secondary sludge (SS) and mixed sludge (MS).

\subsection{Inoculum}

Digested anaerobic sludge from the WWTP reactor of Beirolas (Lisbon, Portugal), and anoxic marine sediments of the Guadiana Estuary (Portugal) were used as inocula. The digested sludge was used in the macroalgae biodegradability and co-digestion tests, while the marine sediment was used in one of the co-digestion tests to compare the two inocula performance. Both inocula were evaluated for the specific methanogenic activity and volatile solids (VS).

\subsubsection{Methanogenic activity mesurements}

Methanogenic activity tests were performed using the pressure transducer technique. The test involves the monitoring of the pressure increase developed in sealed vials fed with non-gaseous substrates (specific acetoclastic activity (SAA) with acetate, $0.030 \mathrm{M}$ ) or pressure decrease in vials previously pressurized with gaseous substrates (specific hydrogenotrophic methanogenic activity (SHMA), in the presence of $\mathrm{H}_{2} / \mathrm{CO}_{2}(80: 20, v / v)$, at 1 bar). Strict anaerobic conditions were maintained. The hand-held pressure transducer was capable of measuring a pressure increase or decrease of two bar $(0 \pm 2202.6 \mathrm{kPa})$ over a range of -200 to $+200 \mathrm{mV}$, with a minimum detectable variation of 0.005 bar. A sensing element consisting of a $2.5 \mathrm{~mm}$ square silicon chip with integral sensing diaphragm is connected to a digital panel meter module and the device is powered by a $7.5 \mathrm{~V}$ DC transformer. The basal medium used in the batch experiments, made up with distilled water, was composed of cysteine- $\mathrm{HCl}\left(0.5 \mathrm{~g} \mathrm{~L}^{-1}\right)$ and sodium bicarbonate $\left(3 \mathrm{~g} \mathrm{~L}^{-1}\right)$, the $\mathrm{pH}$ was adjusted to $7.0 \pm 7.2$ with $\mathrm{NaOH} 8 \mathrm{~N}$ and was prepared under strict anaerobic conditions. The medium was added to the sludge $\left(3 \mathrm{~g} \mathrm{VS} \mathrm{L}^{-1}\right)$ to a working volume of $12.5 \mathrm{~mL}$. Blank assays were performed to discount the methane production due to residual substrate. No calcium or trace-nutrients were added. All methanogenic activity tests were performed in triplicate assays. The methanogenic activity values were corrected to the standard temperature and pressure conditions (STP).

The methane percentage in the biogas was determined by gas chromatography using a chromatograph Varian CP-4900, with a PPU column PPU $\left(T=80^{\circ} \mathrm{C}\right)$ and a TCD detector $\left(T=110^{\circ} \mathrm{C}\right)$. The carrier gas used was helium (150 kPa) and the injected volume was $1 \mathrm{~mL}$.

\subsection{Anaerobic biodegradability assays}

\subsubsection{Macroalgae digestion assays}

Anaerobic biodegradability tests were made with the macroalgae $U, G$ and UE to determine the biochemical methane potential and methane production rates. Batch tests were prepared in triplicate for the different macroalgae species at various percentages of total solids (TS): 1.0, 2.5, and 5.0. Also a blank was prepared in triplicate, containing only inoculum, to measure the methane production of the residual substrate, in order to account only for the methane production from the macroalgae biodegradation. The tests were carried out at mesophilic temperature of $37^{\circ} \mathrm{C}$ and lasted approximately 82 days.

\subsubsection{Macroalgae - sludge co-digestion assays}

After the raw macroalgae biodegradability tests, several batch co-digestion assays were prepared in order to optimize the biogas production. Ulva sp. was chosen to test co-digestion with mixed sludge at different ratios (TS/TS): $15 \% \mathrm{U}+85 \% \mathrm{MS}$, $30 \% \mathrm{U}+70 \% \mathrm{MS}, 60 \% \mathrm{U}+40 \% \mathrm{MS}$, and $80 \% \mathrm{U}+20 \% \mathrm{MS}$. The digestion of each substrate alone (100\% $\mathrm{U}$ and $100 \% \mathrm{MS})$ was also assessed.

For the ratio $15 \%$ macroalgae and $85 \%$ WAS, different co-digestion tests were made with specific objectives, namely: (i) use $G$. vermiculophylla instead of Ulva sp. to test a cultivated macroalgae; (ii) use primary and secondary sludge instead of mixed sludge to test the influence of the different sludge; and, (iii) use anoxic marine sediment as inoculum instead of digested anaerobic sludge to test an inocula from a similar environment as of the macroalgae.

All the co-digestion batch assays were prepared in triplicate with $2.5 \% \mathrm{TS}$, and the VS of waste to VS of inoculum ratio was $2.8 \pm 0.1 \mathrm{~g}_{\text {waste }} \mathrm{g}^{-1}$ inoculum. Blank assays were also prepared in triplicate for both inocula. The tests were performed at mesophilic temperature of $37^{\circ} \mathrm{C}$ and lasted approximately 50 days.

\subsubsection{Procedure}

Anaerobic biodegradability batch assays were performed according to the directives defined in Angelidaki et al. (2009). Bottles were prepared by adding the substrate, inoculum, and basal medium containing $\mathrm{NaHCO}_{3}\left(5 \mathrm{~g} \mathrm{~L}^{-1}\right)$ to a final volume of $50 \mathrm{~mL}$. The $\mathrm{pH}$ was corrected to 7.0-7.2 using $\mathrm{NaOH}$ or $\mathrm{HCl} 2 \mathrm{M}$. The vials were sealed and the headspace flushed with $\mathrm{N}_{2} / \mathrm{CO}_{2}(80: 20 \mathrm{v} / \mathrm{v})$. 
Before incubation, the medium was reduced with $\mathrm{Na}_{2} \mathrm{~S} \cdot 9 \mathrm{H}_{2} \mathrm{O}$, added to a final concentration of $1 \mathrm{mM}$.

The methane accumulated in the vessels headspace was measured by gas chromatography by collecting $500 \mu \mathrm{L}$ of sample volume with a gas-tight syringe. Methane production was corrected for STP conditions. The BMP was determined by unit of waste of VS added to each vial:

$\mathrm{BMP}=\frac{\mathrm{COD}-\mathrm{CH}_{4} \times \alpha}{m \mathrm{VS}}$

where BMP is the biochemical methane production $\left(\mathrm{L} \mathrm{CH}_{4} \mathrm{~kg}^{-1} \mathrm{VS}\right)$, $\mathrm{COD}-\mathrm{CH}_{4}$ is the cumulative methane produced $\left(\mathrm{kg} \mathrm{COD}-\mathrm{CH}_{4}\right), \alpha$ is the theoretical biochemical methane potential ( $350 \mathrm{~L} \mathrm{CH}_{4} \mathrm{~kg}^{-1} \mathrm{COD}$ ), and $m \mathrm{VS}$ is the amount of VS of substrate added ( $\mathrm{kg} \mathrm{VS}$ substrate added).

The anaerobic digestion yield in terms of methane production (yield) was defined as the amount of methane produced during the assays in relation to the theoretical biochemical methane potential:

Yield $=\frac{\mathrm{COD}-\mathrm{CH}_{4}}{\mathrm{COD}-\text { added }} \times 100$

where COD-added corresponds to the COD initially added to each vial ( $\mathrm{kg}$ COD).

Hydrolysis was evaluated considering the percentage of solubilization $\left(P_{\text {Soluble }}\right)$, which represents the percentage of the COD added to the vials that was solubilized during the anaerobic biodegradability assay, as follows:

PSoluble $=\frac{\mathrm{CODs}+\mathrm{COD}-\mathrm{CH}_{4}}{\mathrm{COD} \cdot \text { added }} \times 100$

where CODs is the soluble COD present in the vials at the end of the assay ( $\mathrm{kg} \mathrm{COD}$ ). Note that the COD transformed in biomass growth was not considered in these calculations.

\subsection{Analytical Methods}

Total kjeldahl nitrogen (TKN), ammonium $\left(\mathrm{NH}_{4}^{+}\right)$, TS and VS were measured according to standard methods (APHA, 1998). Total and soluble COD were determined using standard kits (Hach Lange, Düsseldorf, Germany). Sample filtration was performed prior to soluble COD (CODs) determination. Volatile fatty acids (VFA) were determined by HPLC (Jasco, Japan) equipped with a UV detector $(210 \mathrm{~nm})$ and a Chrompack column $\left(6.5 \times 30 \mathrm{~mm}^{2}\right)$ at $60{ }^{\circ} \mathrm{C}$. Sulfuric acid $(0.01 \mathrm{~N})$ was used as mobile phase at a flow rate of $0.6 \mathrm{~mL} \mathrm{~min}^{-1}$.

Methane was analyzed in a gas chromatograph (Chrompack 9001B) equipped with a TCD detector and a Porapak column. Argon was used as carrier gas $\left(13 \mathrm{~mL} \mathrm{~min}^{-1}\right)$. The column, injector, and detector temperatures were 35,110 , and $110^{\circ} \mathrm{C}$, respectively.

The proteins content was determined based on the TKN measurement using the correction factor 6.25 (Bruni et al., 2010; Msuya and Neori, 2008). The total fat content was extracted with diethyl ether in a Soxtec System HT2 1045 extraction unit produced by Tecator (Official Method of Analysis, 2007). Carbohydrates were estimated as the remaining fraction of VS after the determination of proteins and lipids (Alvarez et al., 2010).

\subsection{Data analysis}

An exponential model was used to describe the progress of cumulative methane production obtained from the batch experiments (Eq. (4)):

$M(t)=P\left(1-e^{-k t}\right)$

where $M(t)$ is the methane cumulative production (mg COD- $\mathrm{CH}_{4}$ ), $P$ is the maximum methane production $\left(\mathrm{mg} \mathrm{COD}-\mathrm{CH}_{4}\right), k$ is the methane production rate $\left(\mathrm{d}^{-1}\right)$, and $t$ is the time $(\mathrm{d})$.

\section{Results and discussion}

\subsection{Inocula and substrate characterization}

The inocula characterization is presented in Table 1. Although no SAA was detected in the anoxic marine sediment, the SHMA was higher than in the anaerobic digested sludge.

The results from the four macroalgae (Ulva sp., Enteromorpha sp., Gracilaria sp., and G. vermiculophylla) and three WAS (primary, secondary, and mixed sludge) characterization are shown in Table 2 . The nitrogen content, between $3.5 \%$ and $8.7 \%$, may result in methanogenesis inhibition, if the appropriate measures, such as efficient dilution, are not carried out.

Table 1

Inocula characterization.

\begin{tabular}{llll}
\hline & & Anaerobic digested sludge & Marine sediment \\
\hline VS & $\mathrm{g} \mathrm{L}^{-1}$ & 15.4 & 29.9 \\
SAA & ${\mathrm{g} \mathrm{COD}-\mathrm{CH}_{4} @ \text { STP }}^{-1} \mathrm{VS} \mathrm{d}^{-1}$ & $0.12 \pm 0.02$ & $<0.01$ \\
SHMA & ${\mathrm{g} \mathrm{COD}-\mathrm{CH}_{4} @ \text { STP }}^{-1} \mathrm{VS} \mathrm{d}^{-1}$ & $0.57 \pm 0.13$ & $0.72 \pm 0.37$ \\
\hline
\end{tabular}

Table 2

Characterization of the different substrates (macroalgae and sludge) used in the experiments.

\begin{tabular}{|c|c|c|c|c|c|c|c|c|}
\hline & & Ulva sp. & Enteromorpha sp. & Gracilaria sp. & G. vermiculophylla & MS & PS & SS \\
\hline TS & $\%$ & $15.8 \pm 0.7$ & $14.7 \pm 1.5$ & $20.5 \pm 2.5$ & $20^{b}$ & $5.6 \pm 0.3$ & $8.6 \pm 0.2$ & $3.48 \pm 0.02$ \\
\hline VS & $\%$ & $\mathrm{Nd}$ & $\mathrm{Nd}$ & $\mathrm{Nd}$ & $\mathrm{Nd}$ & $3.8 \pm 0.2$ & $5.5 \pm 0.2$ & $2.56 \pm 0.02$ \\
\hline VS & $\%^{a}$ & $46.9 \pm 2.4$ & $43.1 \pm 2.1$ & $56.7 \pm 3.1$ & $65.3 \pm 0.6$ & $68.4 \pm 0.4$ & $63.5 \pm 0.5$ & $73.5 \pm 0.2$ \\
\hline COD & $\mathrm{g} \mathrm{O}_{2} \mathrm{~g}^{-1}$ waste $^{\mathrm{a}}$ & $0.69 \pm 0.08$ & $0.59 \pm 0.05$ & $0.63 \pm 0.05$ & $0.85 \pm 0.03$ & $1.4 \pm 0.9$ & $1.6 \pm 0.2$ & $1.2 \pm 0.2$ \\
\hline TKN & $\%^{a}$ & $4.1 \pm 0.2$ & $3.5 \pm 0.2$ & $7.6 \pm 0.3$ & $8.7 \pm 0.2$ & $4.3 \pm 0.2$ & $0.3 \pm 0.1$ & $0.6 \pm 0.2$ \\
\hline Proteins & $\%^{a}$ & $25.9 \pm 1.3$ & $22.2 \pm 1.4$ & $47.4 \pm 2.1$ & $54.5 \pm 1.2$ & $27.1 \pm 1.1$ & $2.1 \pm 0.9$ & $3.9 \pm 1.1$ \\
\hline Lipids & $\%^{a}$ & $0.54 \pm 0.02$ & $1.2 \pm 0.1$ & $1.6 \pm 0.3$ & $0.6 \pm 0.2$ & $2.4 \pm 0.8$ & $5.0 \pm 2.7$ & $3.5 \pm 2.8$ \\
\hline Carbohydrates & $\%^{a}$ & $20.5 \pm 1.3$ & $19.7 \pm 1.5$ & $7.7 \pm 2.4$ & $10.2 \pm 1.0$ & $38.8 \pm 0.2$ & $56.4 \pm 1.8$ & $66.1 \pm 1.7$ \\
\hline
\end{tabular}

Nd: not determined.

a Dry weight.

b Abreu et al. (2010). 

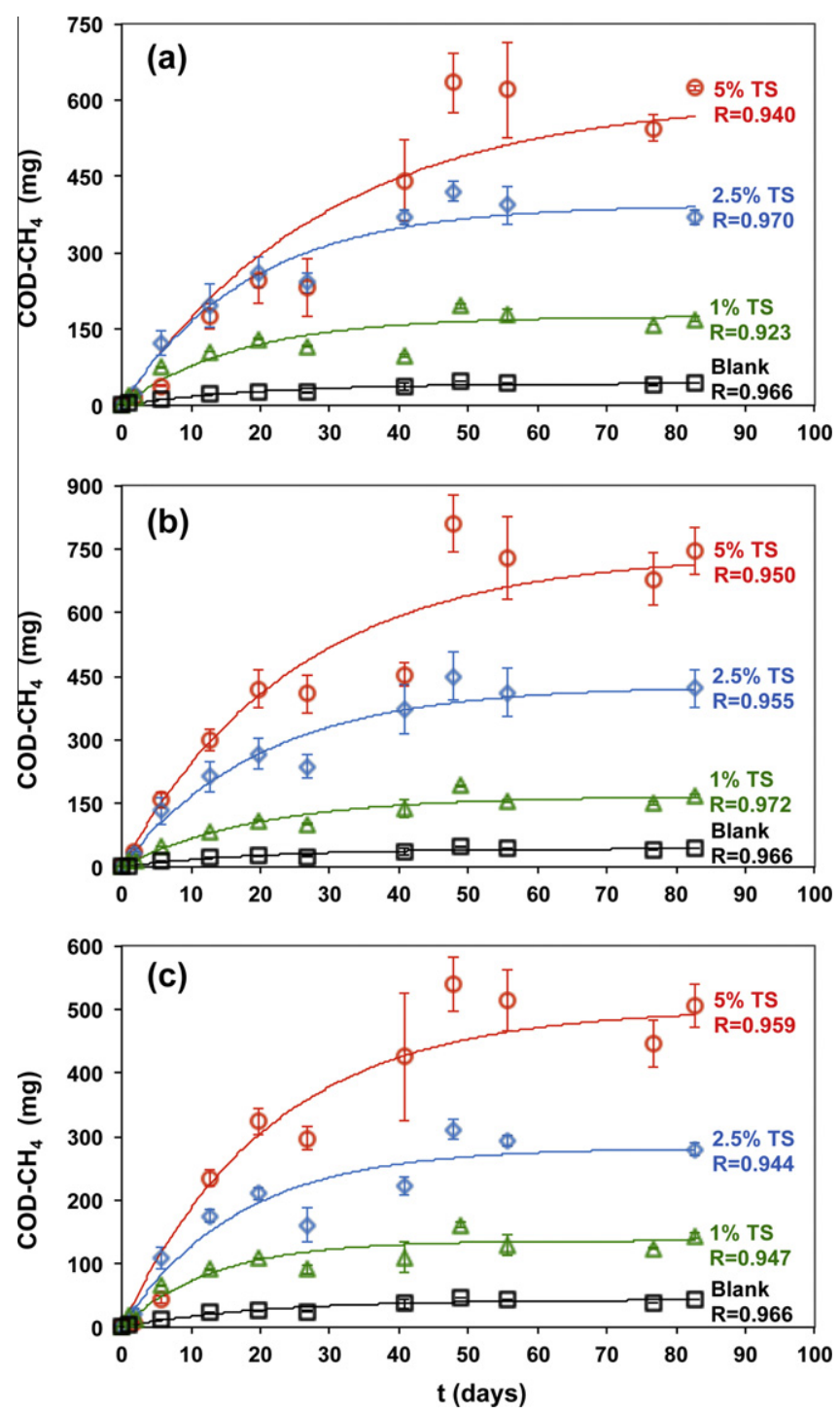

Fig. 1. Cumulative methane production ( $\left.\mathrm{mg} \mathrm{COD}-\mathrm{CH}_{4}\right)$ during anaerobic biodegradability tests with Ulva sp. (a), Gracilaria sp. (b), and Enteromorpha sp. (c). 0\% TS (blank) $(\square), 1 \%$ TS $(\triangle), 2.5 \%$ TS $(\diamond)$, and $5 \%$ TS $(\bigcirc)$. The symbols represent the experimental data with respective standard deviation ( $n=3$ points). The lines represent the predicted data by the exponential model.

\subsection{Macroalgae biochemical methane potential}

The cumulative methane profiles of the macroalgae are shown in Fig. 1. All the assays stabilized approximately after 50 days. The maximum methane production achieved was $740 \pm 79 \mathrm{mg}$ COD- $\mathrm{CH}_{4}$ in the digestion with $5 \%$ TS of Gracilaria sp.
In Table 3 are summarized the results obtained at the end of the biodegradability tests. TKN present in the macroalgae is high, therefore is important to state that ammonium concentrations up to $1500 \mathrm{mg} \mathrm{L}^{-1}$ have no significant adverse effects on the methanogenesis, and above this value it can be inhibitory or toxic (MacCarty, 1964), being pH dependent. However, unionized ammonia inhibits methanogenesis at initial concentrations of $0.1-$ $1.1 \mathrm{~g} \mathrm{~N} \mathrm{~L}^{-1}$. In these assays, the ammonium varied between 53 and $827 \mathrm{mg} \mathrm{NH}_{4}^{+}-\mathrm{N} \mathrm{L}^{-1}$, and the $\mathrm{pH}$ ranged from 7.23 to 7.56 , therefore, despite the high nitrogen content of the macroalgae, no inhibitory levels were reached because of the high dilution used.

The biodegradability tests results (Table 3 ) indicate that Ulva sp. presents a slightly higher specific methane production in relation to Gracilaria sp., which in turn, was more biodegradable than Enteromorpha sp. The BMP obtained within this work was $196 \pm 9 \mathrm{~L} \mathrm{CH}_{4} \mathrm{~kg}^{-1}$ VS for the Ulva sp., $182 \pm 23 \mathrm{~L} \mathrm{CH}_{4} \mathrm{~kg}^{-1}$ VS for the Gracilaria sp., and $154 \pm 7 \mathrm{~L} \mathrm{CH}_{4} \mathrm{~kg}^{-1}$ VS for the Enteromorpha sp., with $2.5 \%$ TS. However, no significant differences were observed in the assays at $1 \%$ and $5 \%$ TS, except an unexpected decrease in the specific methane yield in the assay with $1 \%$ TS of Gracilaria sp. These results suggest that no inhibitory levels were reached with the substrates concentrations and substrate to inoculum ratio tested. However, the methane production rate $(k)$ was small for the assays with 5\%TS probably due to the high substrate to inoculum ratio.

Although Gracilaria sp. contains a higher percentage of VS than Ulva sp., this later has higher carbohydrate content, which is favorable to methanation. According to Briand and Morand (1997), the macroalgae Ulva sp. is characterized by a low content of lignin and a high fraction of hemicellulose, being therefore, a suitable substrate for anaerobic digestion. Moreover, Ulva sp. provides cells with a thinner and simpler morphological structure, and a large surface area, making it easier to break down and digest compared to other macroalgae (Habig et al., 1984; Morand and Briand, 1999; Rigoni-Stern et al., 1990). The macroalgae Enteromorpha sp. had the lowest specific methane production, likely due to its lower VS content and higher refractory fraction. The methane yield (Table 3) was higher than $40 \%$ for Ulva sp. and Gracilaria sp., and around $32 \%$ for the Enteromorpha sp., confirming that less than $50 \%$ of the macroalgae energetic potentials are being availed and that the Enteromorpha sp. is the most difficult to digest.

In general, the $P_{\text {Soluble }}$ was approximately $5 \%$ higher than the methane yield (Table 3 ) and similar to the acidification percentage, indicating that most of the hydrolyzed material was converted to VFA. Then, almost all the VFA formed were converted to methane. The VFA analysis detected acetic, iso-butyric, and formic acids but at concentrations below $50 \mathrm{mg} \mathrm{L}^{-1}$ (data not shown). These results confirm that the methanogenesis and acidogenesis were not inhibited and the rate-limiting step of the overall $\mathrm{AD}$ process was the macroalgae hydrolysis. Therefore, methane yield can be improved applying pre-treatments methods (Bruhn et al., 2011;

Table 3

Experimental results obtained at the end of the macroalgae biodegradability assays.

\begin{tabular}{|c|c|c|c|c|c|c|c|c|c|c|}
\hline \multirow{2}{*}{\multicolumn{2}{|c|}{ Concentration }} & \multicolumn{3}{|l|}{ Ulva sp. } & \multicolumn{3}{|c|}{ Enteromorpha sp. } & \multicolumn{3}{|l|}{ Gracilaria sp. } \\
\hline & & $1 \% \mathrm{TS}$ & $2.5 \% \mathrm{TS}$ & $5 \% \mathrm{TS}$ & $1 \% \mathrm{TS}$ & $2.5 \% \mathrm{TS}$ & $5 \% \mathrm{TS}$ & $1 \% \mathrm{TS}$ & $2.5 \% \mathrm{TS}$ & $5 \% \mathrm{TS}$ \\
\hline \multirow{2}{*}{\multicolumn{2}{|c|}{$\begin{array}{l}\mathrm{VS}_{\text {waste }} / \mathrm{VS}_{\text {inoculum }} \\
\mathrm{pH}\end{array}$}} & 1.18 & 2.87 & 5.74 & 1.07 & 2.64 & 5.27 & 1.43 & 3.47 & 7.02 \\
\hline & & $7.41 \pm 0.08$ & $7.23 \pm 0.03$ & $7.23 \pm 0.07$ & $7.35 \pm 0.17$ & $7.54 \pm 0.14$ & $7.56 \pm 0.05$ & $7.41 \pm 0.02$ & $7.27 \pm 0.06$ & $7.53 \pm 0.04$ \\
\hline $\mathrm{COD}_{\mathrm{s}}$ & $\mathrm{g} \mathrm{O}_{2} \mathrm{~L}^{-1}$ & $0.27 \pm 0.06$ & $0.60 \pm 0.09$ & $3.52 \pm 0.69$ & $0.23 \pm 0.04$ & $0.98 \pm 0.11$ & $4.22 \pm 1.19$ & $0.27 \pm 0.04$ & $0.66 \pm 0.03$ & $1.43 \pm 0.20$ \\
\hline $\mathrm{NH}_{4}^{+}-\mathrm{N}$ & $\mathrm{mg} \mathrm{L}^{-1}$ & $53 \pm 65$ & $340 \pm 201$ & $466 \pm 84$ & $121 \pm 15$ & $302 \pm 115$ & $611 \pm 94$ & $140 \pm 4$ & $528 \pm 213$ & $827 \pm 152$ \\
\hline$P$ & $\mathrm{mg} \mathrm{COD}-\mathrm{CH}_{4}$ & $175 \pm 15$ & $394 \pm 31$ & $606 \pm 61$ & $136 \pm 17$ & $282 \pm 26$ & $501 \pm 50$ & $167 \pm 17$ & $427 \pm 49$ & $740 \pm 79$ \\
\hline BMP & $\mathrm{LCH}_{4} \mathrm{~kg}^{-1} \mathrm{VS}$ & $192 \pm 2$ & $196 \pm 9$ & $167 \pm 13$ & $153 \pm 11$ & $154 \pm 7$ & $148 \pm 13$ & $148 \pm 5$ & $182 \pm 23$ & $170 \pm 16$ \\
\hline Yield & $\%$ & $43 \pm 1$ & $44 \pm 2$ & $38 \pm 3$ & $32 \pm 2$ & $32 \pm 1$ & $31 \pm 3$ & $38 \pm 1$ & $47 \pm 6$ & $44 \pm 4$ \\
\hline$P_{\text {Soluble }}$ & $\%$ & $48 \pm 1$ & $48 \pm 2$ & $49 \pm 1$ & $37 \pm 2$ & $39 \pm 1$ & $45 \pm 4$ & $43 \pm 1$ & $51 \pm 6$ & $50 \pm 5$ \\
\hline$k$ & $\mathrm{~d}^{-1}$ & $0.058 \pm 0.009$ & $0.054 \pm 0.006$ & $0.034 \pm 0.007$ & $0.051 \pm 0.006$ & $0.049 \pm 0.007$ & $0.040 \pm 0.006$ & $0.076 \pm 0.010$ & $0.060 \pm 0.008$ & $0.047 \pm 0.007$ \\
\hline
\end{tabular}


Nielsen and Heiske, 2011; Sialve et al., 2009) that increase the hydrolysis rate.

\subsection{Macroalgae-sludge co-digestion}

The cumulative methane production profiles during anaerobic co-digestion of Ulva sp. and mixed sludge are shown in Fig. 2, while Table 4 summarizes the results at the end of the biodegradability assays.

The BMP of the assays with $100 \% \mathrm{MS}$ was $335 \pm 27 \mathrm{~L} \mathrm{CH}_{4} \mathrm{~kg}^{-1} \mathrm{VS}$ and in the assay with $100 \% \mathrm{U}$ was $196 \pm 9 \mathrm{~L} \mathrm{CH}_{4} \mathrm{~kg}^{-1} \mathrm{VS}$ (Table 4). This difference is only due to the available organic matter (COD) in the vials. The methane yield was similar for all the assays, in the range $42-45 \%$, indicating a similar degree of biodegradation of both substrates. A remarkable result concerns the faster production of methane during the first 15 days of experiment, even in the test with only $20 \%$ of MS, comparing with the $100 \% \mathrm{U}$ test. The methane production rate increased significantly (2-3) times in the co-digestion assays, compared to the digestion of $100 \% \mathrm{U}$. The highest value of $k$ was obtained in the co-digestion assay with $15 \% \mathrm{U}$ and $85 \% \mathrm{MS}$ $\left(0.146 \pm 0.037 \mathrm{~d}^{-1}\right)$.

This results indicate that the co-digestion of macroalgae with WAS seems an attractive choice, with a synergetic effect. The methane production rate of the co-digestion process, compared with the WAS digestion alone was increased $26 \%$ and the overall biodegradability was not negatively affected.

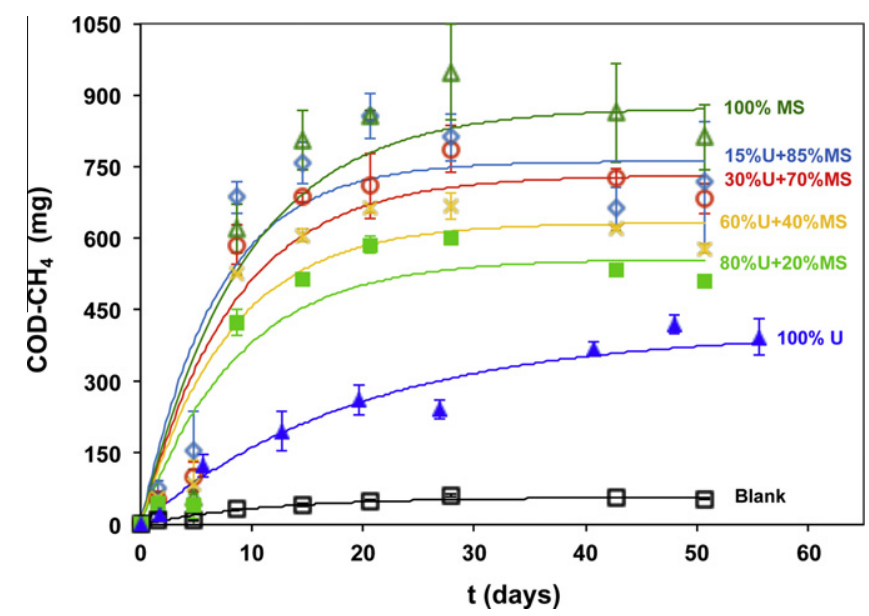

Fig. 2. Cumulative methane production ( $\left.\mathrm{mg} \mathrm{COD}-\mathrm{CH}_{4}\right)$ during anaerobic co-digestion tests with Ulva sp. (U) and mixed sludge (MS). Blank ( $\square, R=0.985), 100 \% \mathrm{U}$ ( $\boldsymbol{\Delta}$, $R=0.962), \quad 80 \% \mathrm{U}+20 \% \mathrm{MS} \quad(\square, R=0.990), \quad 60 \% \mathrm{U}+40 \% \mathrm{MS} \quad(\mathrm{X}, \quad R=0.992)$, $30 \% \mathrm{U}+70 \% \mathrm{MS}(\bigcirc, R=0.991), 15 \% \mathrm{U}+85 \% \mathrm{MS}(\diamond, R=0.976)$, and $100 \% \mathrm{MS}(\triangle$, $R=0.988$ ). The symbols represent the experimental data with respective standard deviation ( $n=3$ points). The lines represent the predicted data by the exponential model.
Besides the $U$ and MS co-digestion, several tests were made changing the macroalgae species and cultivation method ( $U$ vs. GV), co-substrate (MS vs. PS or SS), and inoculum (anaerobic suspended sludge $v s$. anoxic marine sediment). The cumulative methane production profile is shown in Fig. 3 and the final results are presented in Table 5 .

The BMP, of the "natural growth" macroalgae (Ulva sp.) and the "cultivated" macroalgae (G. vermicullophyla) is identical, $296 \pm 19$ and $294 \pm 4 \mathrm{~L} \mathrm{CH}_{4} \mathrm{~kg}^{-1}$ VS. Also the $P_{\text {Soluble }}$ is very similar. The main difference between those macroalgae refers to the methane production rate, i.e., the $k$ in the assay with $U$ is 1.7 times higher than in the assay with GV (Table 5). This difference is very important because it may represent, for instance, the difference between an anaerobic digester operating with a hydraulic retention time of 10 or $20 \mathrm{~d}$, with all the increasing investment and operational costs that such difference involves. Therefore, the use of Ulva sp. seems economically more attractive.

Regarding the different sludge tested, the highest BMP was obtained with the PS, i.e., $358 \mathrm{~L} \mathrm{CH}_{4} \mathrm{~kg}^{-1} \mathrm{VS}$ (Table 5). This difference is explained by the higher theoretical methane potential of the PS, since the methane yield and $P_{\text {Soluble }}$ are very similar. As expected, the secondary sludge is less suitable for co-digest with macroalgae, with methane yield $10 \%$ smaller.

The last test consisted in the use of anoxic marine sediment instead of the digested anaerobic sludge. However, this alternative was not positive for the co-digestion of MS with the Ulva sp. since the parameters analyzed, i.e., methane yield, BMP, and $P_{\text {Soluble }}$ were slightly lower than in the test with anaerobic sludge (Table 5). But

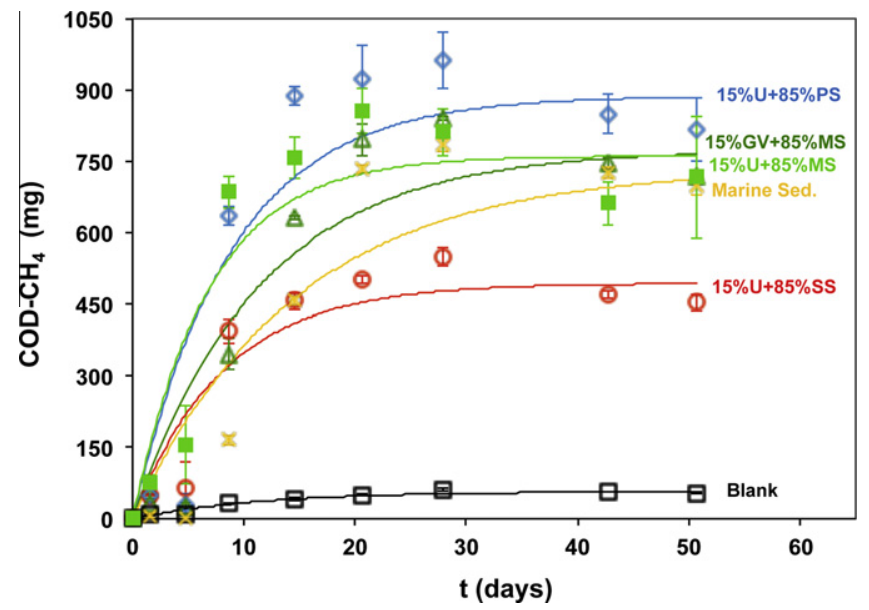

Fig. 3. Cumulative methane production $\left(\mathrm{mg} \mathrm{COD}-\mathrm{CH}_{4}\right)$ during anaerobic co-digestion tests with: Blank ( $\square, \quad R=0.985), \quad 15 \% \mathrm{U}+85 \% \mathrm{MS} \quad(\square, R=0.976)$, $15 \% \mathrm{GV}+85 \% \mathrm{MS}(\triangle, R=0.993), 15 \% \mathrm{U}+85 \% \mathrm{PS}(\diamond, R=0.992), 15 \% \mathrm{U}+85 \% \mathrm{SS}(\bigcirc$, $R=0.985)$, and $15 \% \mathrm{U}+85 \% \mathrm{MS}$ and marine sediment as inoculum $(\mathrm{X}, R=0.994)$. The symbols represent the experimental data with respective standard deviation ( $n=3$ points). The lines represent the predicted data by the exponential model.

Table 4

Experimental results obtained at the end of Ulva sp. (U) and mixed sludge (MS) co-digestion assays.

\begin{tabular}{|c|c|c|c|c|c|c|c|}
\hline & & $100 \% \mathrm{MS}$ & $15 \% \mathrm{U}+85 \% \mathrm{MS}$ & $30 \% \mathrm{U}+70 \% \mathrm{MS}$ & $60 \% \mathrm{U}+40 \% \mathrm{MS}$ & $80 \% \mathrm{U}+20 \% \mathrm{MS}$ & $100 \% \mathrm{U}$ \\
\hline $\mathrm{pH}$ & & $7.50 \pm 0.03$ & $7.47 \pm 0.06$ & $7.46 \pm 0.01$ & $7.46 \pm 0.01$ & $7.47 \pm 0.03$ & $7.23 \pm 0.03$ \\
\hline $\mathrm{COD}_{\mathrm{s}}$ & $\mathrm{g} \mathrm{O}_{2} \mathrm{~L}^{-1}$ & $0.37 \pm 0.01$ & $0.48 \pm 0.04$ & $0.59 \pm 0.12$ & $0.96 \pm 0.61$ & $0.86 \pm 0.07$ & $0.60 \pm 0.09$ \\
\hline $\mathrm{NH}_{4}^{+}-\mathrm{N}$ & $\mathrm{mg} \mathrm{L}^{-1}$ & $900 \pm 80$ & $1440 \pm 490$ & $650 \pm 80$ & $1180 \pm 650$ & $650 \pm 60$ & $340 \pm 201$ \\
\hline$P$ & $\mathrm{mg} \mathrm{COD}-\mathrm{CH}_{4}$ & $874 \pm 94$ & $761 \pm 100$ & $732 \pm 55$ & $632 \pm 41$ & $556 \pm 41$ & $406 \pm 30$ \\
\hline BMP & $\mathrm{LCH}_{4} \mathrm{~kg}^{-1} \mathrm{VS}$ & $335 \pm 27$ & $296 \pm 19$ & $285 \pm 19$ & $257 \pm 4$ & $229 \pm 3$ & $196 \pm 9$ \\
\hline Yield & $\%$ & $45 \pm 4$ & $42 \pm 3$ & $43 \pm 3$ & $44 \pm 1$ & $43 \pm 1$ & $44 \pm 2$ \\
\hline$P_{\text {Soluble }}$ & $\%$ & $46 \pm 4$ & $44 \pm 3$ & $45 \pm 3$ & $47 \pm 2$ & $47 \pm 1$ & $48 \pm 2$ \\
\hline$k$ & $\mathrm{~d}^{-1}$ & $0.108 \pm 0.027$ & $0.146 \pm 0.037$ & $0.120 \pm 0.026$ & $0.127 \pm 0.029$ & $0.116 \pm 0.028$ & $0.051 \pm 0.008$ \\
\hline
\end{tabular}


Table 5

Experimental results obtained at the end of macroalgae and sludge co-digestion assays.

\begin{tabular}{|c|c|c|c|c|c|c|}
\hline \multirow[t]{2}{*}{ Inoculum } & & \multicolumn{3}{|c|}{ Anaerobic digested sludge } & \multicolumn{2}{|c|}{ Marine sediment } \\
\hline & & $15 \% \mathrm{U}+85 \% \mathrm{MS}$ & $15 \% \mathrm{GV}+85 \% \mathrm{MS}$ & $15 \% U+85 \% P S$ & $15 \% U+85 \% S S$ & $15 \% U+85 \% M S$ \\
\hline $\mathrm{pH}$ & & $7.47 \pm 0.06$ & $7.49 \pm 0.01$ & $7.46 \pm 0.01$ & $7.59 \pm 0.04$ & $7.35 \pm 0.03$ \\
\hline $\mathrm{COD}_{\mathrm{s}}$ & $\mathrm{g} \mathrm{O}_{2} \mathrm{~L}^{-1}$ & $0.48 \pm 0.04$ & $1.34 \pm 0.48$ & $0.69 \pm 0.32$ & $0.37 \pm 0.03$ & $0.45 \pm 0.22$ \\
\hline $\mathrm{NH}_{4}^{+}-\mathrm{N}$ & $\mathrm{mg} \mathrm{L}^{-1}$ & $1440 \pm 490$ & $860 \pm 130$ & $670 \pm 110$ & $890 \pm 120$ & $600 \pm 30$ \\
\hline$P$ & $\mathrm{mg} \mathrm{COD}-\mathrm{CH}_{4}$ & $761 \pm 100$ & $775 \pm 52$ & $888 \pm 68$ & $494 \pm 40$ & $735 \pm 35$ \\
\hline BMP & $\mathrm{LCH}_{4} \mathrm{~kg}^{-1} \mathrm{VS}$ & $296 \pm 19$ & $294 \pm 4$ & $358 \pm 2$ & $170 \pm 5$ & $283 \pm 5$ \\
\hline Yield & $\%$ & $42 \pm 3$ & $42 \pm 1$ & $43 \pm 1$ & $32 \pm 1$ & $40 \pm 1$ \\
\hline$P_{\text {Soluble }}$ & $\%$ & $44 \pm 3$ & $46 \pm 2$ & $45 \pm 1$ & $33 \pm 1$ & $42 \pm 1$ \\
\hline$k$ & $\mathrm{~d}^{-1}$ & $0.146 \pm 0.037$ & $0.087 \pm 0.022$ & $0.113 \pm 0.031$ & $0.122 \pm 0.028$ & $0.068 \pm 0.021$ \\
\hline
\end{tabular}

more important, the methane production rate was much lower and a lag phase of $5 \mathrm{~d}$ was observed. These differences may be explained by the fact that the rate-limiting step was found to be the hydrolysis. Therefore, in this context there is no real advantage in using more adapted/active inoculum.

Despite the high nitrogen content of macroalgae there was no ammonia inhibition in all co-digestion assays. It is also possible to verify by the results presented in Tables 4 and 5, i.e., low soluble COD, small VFA concentration (data not show), and the similarity between the values of methane yield and $P_{\text {Soluble, that the metha- }}$ nogenesis was not inhibited and, also in this case, the limiting step of the anaerobic digestion process was the hydrolysis.

From the point of view of a WWTP, it is possible to envisage macroalgae cultivation as an important post treatment method, where carbon dioxide and nutrients are used to the macroalgae growth, and macroalgae are subsequently used for energy production. The co-digestion of macroalgae with WAS (15\% U; $85 \% \mathrm{MS})$ is feasible at a rate of methane production $26 \%$ higher than WAS alone. From the technical point of view, the research in the field of macroalgae AD suggests that a full-scale investment is possible, where energy and a bio-fertilizer are produced concomitantly with pollution mitigation.

\section{Conclusions}

The maximum specific methane production obtained was $196 \pm 9 \mathrm{~L} \mathrm{CH}_{4} \mathrm{~kg}^{-1} \mathrm{VS}$ of Ulva sp., at $2.5 \%$ TS. The limiting step of the overall anaerobic digestion process was the hydrolysis. The co-digestion of macroalgae with WAS (15\% U; $85 \% \mathrm{MS}$ ) is feasible at a rate of methane production $26 \%$ higher than WAS alone without decreasing the overall biodegradability of the substrate (42$45 \%$ methane yield). From the technical point of view, the research in the field of macroalgae AD suggests that a full-scale investment is possible, where energy and a bio-fertilizer are produced concomitantly with pollution mitigation.

\section{Acknowledgements}

The authors acknowledge the financial support of the "Fundação para a Ciência e a Tecnologia" through the grant given to José Carlos Costa (SFRH/BDP/48962/2008) and Ana Nobre (SFRH/ BPD/64582/2009).

We would like to thank the following people for providing the samples used in this work: Celia Rodrigues (SapalSado), Dr. Helena Abreu and Dr. Rui Pereira (Algaplus), Dr. Carlos Vale (IPIMAR), and Eng ${ }^{\circ}$ Pedro Povoa and Dr. Ana Paula Teixeira (SIMTEJO).

\section{References}

Abreu M.H., Pereira R., Figuerona F., Buschmann A., Jarish C., Sousa-Pinto I. Integrated multi-trophic aquaculture in Portugal: experiments with the red seaweed Gracilaria vermiculophylla (Ohmi) Papenfuss in a sole and turbot fish farm. Aquaculture 2010, Meeting of the world Aquaculture Society, San Diego, USA, March 1-5, 2010

Alvarez, J.A., Otero, L., Lema, J.M., 2010. A methodology for optimising feed composition for anaerobic digestion co-digestion of agro-industrial wastes. Bioresour. Technol. 101, 1153-1158.

Angelidaki, I., Alves, M.M., Bolzonella, D., Borzacconi, L., Campos, L., Guwy, A.J., Kalyuzhnyi, S., Jenicek, P., van Lier, J.B., 2009. Defining the biomethane potential (BMP) of solid organic wastes and energy crops: a proposed protocol for batch assays. Water Sci. Technol. 59, 927-934.

APHA, AWWA, WPCF, 1998. Standard Methods for the Examination of Water and Wastewater (17th ed.). American Public Health Association, Washington, D.C.

Appels, L., Baeyens, J., Degrève, J., Dewil, R., 2008. Principles and potential of the anaerobic digestion of waste-activated sludge. Prog. Energy Combust. 34, 755781.

Appels, L., Lauwers, J., Degrève, J., Helsen, L., Lievens, B., Willems, K., Van Impe, J., Dewil, R., 2011. Anaerobic digestion in global bioenergy production: Potential and research challenges. Renewable Sustainable Energy Rev. 15, 4295-4301.

Briand, X., Morand, P., 1997. Anaerobic digestion of Ulva sp. 1. Relationship between Ulva composition and methanisation. J. Appl. Phycol. 9, 511-524.

Bruhn, A., Dahl, J., Nielsen, H.B., Nikolaisen, L., Rasmussen, M.B., Markager, S., Olesen, B., Arias, C., Jensen, P.D., 2011. Bioenergy potential of Ulva lactuca: biomass yield, methane production and combustion. Bioresour. Technol. 102 , 2595-2604.

Bruni, E., Jensen, A.P., Angelidaki, I., 2010. Comparative study of mechanical, hydrothermal, chemical and enzymatic treatments of digested biofibers to improve biogas prodution. Bioresour. Technol. 101, 8713-8717.

Cecchi, F., Pavan, P., Mata-Alvarez, J., 1996. Anaerobic co-digestion of sewage sludge: application to the macroalgae from the Venice lagoon. Resour. Conserv. Recycl. 17, 57-66.

Chynoweth, D.P., Owens, J.M., Legrand, R., 2001. Renewable methane from anaerobic digestion of biomass. Renewable Energy 22, 1-8.

Directive 2009/28/EC of the European Parliament and of the Council of 23 April 2009 on the promotion of the use of energy from renewable sources and amending and subsequently repealing Directives 2001/77/EC and 2003/30/EC. Official Journal of the European Union 2009; L 140:16-62.

Gao, K., Mickinley, K., 1994. Use of macroalgae for marine biomass production and CO2 remediation: a review. J. Appl. Phycol. 6, 45-60.

Gunasselan, N., 1987. Anaerobic digestion of biomass for methane production: a review. Biomass Bioenergy 13, 83-114.

Habig, C., DeBusk, T.A., Ryther, J.H., 1984. The effect of nitrogen content on methane production by the marine algae Gracilaria tikvahiae and Ulva sp. Biomass 4, 239251.

Hansson, G., 1983. Methane production from marine, green macroalgae. Resour. Conserv. Recycl. 8, 185-194.

Jones, C.S., Mayfield, S.P., 2011. Algae biofuels: versatility for the future of bioenergy. Curr. Opin. Biotechnol. 23, 1-6.

Labatut, R.A., Angenent, L.T., Scott, N.R., 2010. Biochemical methane potential and biodegradability of complex organic substrates. Bioresour. Technol. 102, 22552264.

MacCarty P.L., 1964. Anaerobic waste treatment Fundamentals. Part 3. Public Works, 91-94.

Morand, P., Briand, X., 1999. Anaerobic digestion of Ulva sp. 2. Study of Ulva degradation and methanisation of liquefaction juices. J. Appl. Phycol. 11, 165177.

Morand, P., Chalier, R.H., Mazé, J., 1990. European bioconversion projects and realizations for macroalgal biomass: Saint-Cast-Le-Guildo (France) experiment. Hydrobiologia 204 (205), 301-308.

Morand, P., Briand, X., Charlier, R.H., 2006. Anaerobic digestion of Ulva sp 3. Liquefaction juices extraction by pressing and a technico-economic budget. J. Appl. Phycol. 18, 741-755.

Msuya, F.E., Neori, A., 2008. Effect of water aeration and nutrient load level on biomass yield, $\mathrm{N}$ uptake and protein content of the seaweed Ulva lactuca cultured in seawater tanks. J. Appl. Phycol. 20, 1021-1031.

Nielsen, H.B., Heiske, S., 2011. Anaerobic digestion of macroalgae: methane potentials, pre-treatment, inhibition and co-digestion. Water Sci. Technol. 64, 1723-1729.

Nkemka, V.N., Murto, M., 2010. Evaluation of biogas production from seaweed in batch tests and in UASB reactors combined with the removal of heavy metals. J. Environ. Manage. 91, 1573-1579. 
Official Methods of Analysis. Official Method 2003.05, 18th ed. AOAC International, Gaithersburg, MD, 2007.

Peu, P., Sassi, J.F., Girault, R., Picard, S., Saint-Cast, P., Béline, F., Dabert, P., 2011. Sulphur fate and anaerobic biodegradation potential during co-digestion of seaweed biomass (Ulva sp.) with pig slurry. Bioresour. Technol. 102, 1079410802.

Rigoni-Stern, S., Rismondo, R., Zilio-Grandi, F., Szpyrkowicz, L., Vigato, P.A., 1990. Anaerobic digestion of nitrophilic algal biomass from the Venice lagoon. Biomass 23, 179-199.
Schamm, W., Lehnberg, W., 1984. Mass culture of brackish-water-adapted seaweeds in sewage-enriched seawater. II: Fermentation for biogas production. Hydrobiologia 116 (117), 282-287.

Sialve, B., Bernet, N., Bernard, O., 2009. Anaerobic digestion of microalgae as a necessary step to make microalgal biodiesel sustainable. Biotechnol. Adv. 27, 409-416.

Yen, H.W., Brune, D.E., 2007. Anaerobic co-digestion of algal sludge and waste paper to produce methane. Bioresour. Technol. 98, 130-134. 